\section{Fiscaoeconomia}

E-ISSN: 2564-7504

2021, Volume 5, Issue 2, 454-469

https://dergipark.org.tr/tr/pub/fsecon
Research Article/Araştırma Makalesi

Submitted/Geliş: 31.01.2021

Accepted/Kabul: 08.03.2021

Doi: $10.25295 /$ fsecon. 871698

\title{
Politik Bağlamda Yeni Eleştirel Teori: Özne ve İktidar Sorunsalları
}

New Critical Theory in the Context of Politics: The Problematics of Subject and Power

\section{İnan AKDAĞ ${ }^{1}$}

\section{Öz}

Eleştirel teorinin ortaya çııışı, yazılı tarihin başlarına kadar gitmektedir. Insanlık, çevresine, sürekli eleştirel bir çerçeveden bakmıştır. Bu bağlamda sistematik bakış açısı, zamanla, gelenekler yaratmışırı. Bu çalışmada amaç, sistematik eleştiri bakış açısı olan eleştirel teori ve o gelenekten gelen yeni eleştirel teoriyi incelemektir. Yeni eleştirel teori, 1960 'larla birlikte ortaya çıkan, klasik eleştirel teori ile süreklilik içerisinde kopuş ilişkisi olan bir düşünce sistemidir. Post modern felsefeden temel alan bu bakış açısı, temelinde klasik eleştirel teorinin izlerini taşımış ancak klasik eleştirel teoriyi aşmıştır. Özne ve iktidar olgusuna bakış açısından yeni eleştirel teoriyi irdeleyen bu çalışma, klasik eleştirel teori ile yeni eleştirel teori arasında süreklilik içerisinde kopuş ilişkisi tespit etmiştir. Klasik teori, özne konusunda sınıfları ve onların arasında ayrıcalıklı özne olarak iş̧̧i sınıfını vurgularken yeni eleştirel teori, özne yerine özne konumlarını ve çoğul özneler olarak kimlikleri ikame etmiştir. Ek olarak, klasik eleştirel teori, iktidara gelmeyi savunurken yeni eleştirel teori iktidar olgusuna mesafeli yaklaşmışıı. Politik anlamda, klasik eleştirel teori, politik proje olarak sosyalizm hedefi koyarken yeni eleştirel teori, liberal demokrasi içerisinde reform arayışı içerisindedir. Sınıfsal kökleri itibarıyla, klasik eleştirel teori, işçi sınıfının düşünce biçimiyken yeni eleştirel teori küçük burjuvazinin düşünce tarzı olmuştur. Çalışmanın kapsamı, 1968 sonrası biçimlenen yeni eleştirel teoridir. Çalışmanın hipotezi, politik bağlamda yeni eleştirel teori, klasik eleştirel teoriden süreklilik içinde kopuş anlamına gelmesidir.

Jel Kodları: Z00, Z10, Z19

Anahtar Kelimeler: Eleştirel Teori, Yeni Eleştirel Teori, Post Marksizm, Özne, Iktidar

\footnotetext{
${ }^{1}$ Dr. Öğr. Üyesi, Amasya Üniversitesi Merzifon iïBF, Siyaset Bilimi ve Kamu Yönetimi, inanakdag@yahoo.com, ORCID ID: 0000-0001-5531-403X
}

Citation/Atıf: Akdağ, ì. (2021). Politik bağlamda yeni eleştirel teori: Özne ve iktidar sorunsalları. Fiscaoeconomia, 5(2), 454-469. doi: 10.25295/fsecon.871698 
Akdağ, i. (2021). Politik bağlamda yeni eleştirel teori: Özne ve iktidar sorunsalları. Fiscaoeconomia, 5(2), 454-469. doi: 10.25295/fsecon.871698

\begin{abstract}
The emergence of critical theory goes beyond to the beginning of written history. Humanity had continuously engaged critically with its environment. In this context, systematical approach has created traditions. The aim of this study is to analyze the critical theory which has a systematic point of view and the new critical theory from which the critical theory has emerged. New critical theory was born in the 1960s, was a system of thought and there was a break in the continuity relationship with classical critical theory. This view based on postmodern philosophy and bears the traces of classical critical theory, but it went beyond it. This study which examined the new critical theory in relation to subject and power, identified a break in continuity between classical critical theory and the new one. If classical theory emphasizes classes in the subject of subject and highlight working class as the privileged subject, new critical theory substitutes subject positions for identities as plural subjects. Moreover, if classical critical theory defends the assumption of power, new critical theory takes a distanced position on the phenomenon of power. Politically, if classical critical theory targets socialism as a political project, new critical theory seeks reform in liberal democracy. As class roots, if classical critical theory is the thought form of the working class, new critical theory becomes the thought form of petty bourgeoisie. Therefore, the political project of the working class is rejected by the new critical theory. The area of this study is the new critical theory born after 1968. The hypothesis of this study is that there is a break in the continuity relationship between new critical theory and classical critical theory in political terms.
\end{abstract}

Jel Codes: Z00, Z10, Z19

Keywords: Critical Theory, New Critical Theory, Post Marxism, Subject, Power

\title{
1. Giriş
}

Toplumsal yaşamın çelişkili yapısı, eleştirel teorinin ortaya çıkışını, yazılı tarihin başlarına kadar götürmüştür. Atina Şehir Devleti' nin, Socrates'i, gençleri baştan çıkartıyor diye ölüme mahkûm etmesiyle birlikte eleştirel teorinin serüveni başlamıştır ve teorinin, antik dünyada, ilk örneğinin milattan önceki yıllarda görünmesine yol açmıştır. Stephen Eric Bronner (2011: 1), eleştirel teorinin, Socrates'in mirası üzerine geliştiğini belirtmiş̧ir. $O$ dönemlerden itibaren eleştirel teori, dönemsel olarak zayıf ve bazen de kuvvetli bir biçimde, toplumsal hayatta kendisini konumlandırmıştır.

Eleştirel teori, pozisyonu bakımından tarihsel bir içerik kazanmıştır. İyi ile kötü, geçmiş ile gelecek, doğru ile yanlış gibi karşıtlıklarda karşılaştırmalı çerçevede kendisini var etmiştir. Eleştirel teori, toplumsal hayatın her alanına eleştiri silahıyla müdahalede bulunmuştur. Doğaldır ki eleştirel teoriyi, tarihsel-toplumsal koşullar inşa etmiştir. Koşulların değişimi ile eleştirel teoride kendisini yeniden organize etmiştir ve yeni biçimlerde toplumsal hayatta yerini almıştır.

Eleştirel teori, 20. yy'da Marksizmin bir tip yorumu olan Frankfurt Okulu ile özdeşleşmiştir. Ancak eleştirel teori, tarihsel olarak, salt Marksizm ile özdeşleştirilemez. Karl Marx'dan önce Imamnuel Kant, modern dönem eleştirel felsefenin başlatıcısı olarak kabul edilmektedir. Koşulların değişimi sonrası eleştirel teori, Marksizmin bünyesine geçmiştir. Bunda en önemli 
Akdağ, i. (2021). Politik bağlamda yeni eleştirel teori: Özne ve iktidar sorunsalları. Fiscaoeconomia, 5(2), 454-469. doi: 10.25295/fsecon.871698

etken, kapitalizmin egemen bir üretim tarzı olarak toplumsal yapıyı dönüştürmesidir ve Marksizmin alt sınıf olan işçi sınıfının kuramı olmasıdır.

20. yy’da Marksizm, köklü revizyona uğramıştır. Özellikle Rus Devrimi sonrası Batı Avrupa Marksizmi, Marx'ın klasik toplumsal yapı şeması olan ekonomik altyapı ve politik, ideolojik, felsefi üstyapı kavramsallaştırmasını esnetmeye başlamıştır. Antonio Gramsci ile başlayan, Frankfurt Okulu'nun da içinde olduğu akım, altyapı ekonomik indirgemecilikten uzaklaşmış ve üstyapı üzerine odaklanmıştır. Artık Batı Avrupa Marksizmi, ekonomi yerine, hukuk, politika, ideoloji ve felsefe gibi üstyapı kerteler ile uğraşı içerisinde olmuştur. 1968 Gençlik Hareketleri ile bu gelişme yeni bir aşamaya geçmiştir ve bu dönemin ürünü olan yapısalcı Marksizm ile altyapı ile üstyapı arasındaki ilişki göreli özerk olarak tanımlanmıştır. Daha sonra ortaya çıkan post Marksizm ile ise alt yapı ile üstyapı arasındaki ilişki özerk olarak konumlandırılmıştır ve ekonomi, hukuk, politika, ideoloji ve felsefe kerteleri birbirinden bağımsız olarak ele alınmıştır. Bu gelişmeyle birlikte bu düşünce biçimi kendisini yeni eleştirel teori olarak belirlemiştir.

Bu çalışmanın amacı, yeni eleştirel teorinin, özne ve iktidar anlayışlarını politik bağlamda irdelemektir. Çalışmanın kapsamı, 1968 sonrası biçimlenen yeni eleştirel teoridir. Çalışmanın hipotezi, politik bağlamda yeni eleştirel teorinin, klasik eleştirel teoriden, süreklilik içinde kopuş anlamına gelmesidir.

\section{Kavramsal Çerçeve ve Literatür}

Eleştirel teorinin kökleri Antik Yunan'a kadar gitmektedir. Bu dönem sadece toplum felsefesi boyutunda olan eleştirel teori, Immanuel Kant [1724-1804) ile modern döneme taşınmıştır. Idealist bir içerikle karşımıza çıkan bu eleştirel felsefe anlayışı, sanayileşmeyle birlikte materyalist bir içerik kazanmıştır. Batı Avrupa'da yaşanan büyük toplumsal alt üst oluşlarla birlikte eleştirel teori de yeni bir boyuta evrilmiştir. Sınıfsal anlamda yeni filizlenen işçi sınıfıyla birlikte eleştirel teori, sınıfsal olarak, küçük burjuva içeriğinden giderek iş̧̧i sınıfı düşünürlerine geçmiş ve böylece yeni bir biçime dönüşmüştür.

Klasik anlamda eleştirel teori, Karl Marx'la (1818-1883) birlikte sistematik bir biçim kazanmıştır. Toplumsal hayatın her alanı, ekonomi, politika, ideoloji, kısaca bütün boyutları, Marx tarafından eleştiriye uğramıştır. Çağdaşlarından farkı, eleştirisi, sistemi aşma hedefli bir biçime ulaşmıştır. İnsanı praksis içerisinde kavrayan Marx, toplumsal yapının yoksanarak aşılması gerektiğini ileri sürmüştür. Praksisi, sınıflar çerçevesinde kavrayan Marx'a göre dönüşüm, sanayi toplumun bir ürünü olan işçi sınıfı tarafından sağlanacaktır. Avrupa merkezli 1848 Devrimleriyle birlikte eleştirel teori, mevcut sisteme köklü eleştiri getirmeye başlamıştır. Artık eleştirel teori, mevcut sistem içinde reform değil sistemi aşma çabası olarak biçimlenmiştir. 1871 Paris Komünü ve 1917 Rus Devrimiyle birlikte eleştirel teorinin yükselişe geçtiği görülmüştür. Daha sonra, tarihsel olarak, iş̧̧i sınıfının geri çekilişi ve Almanya, İtalya örneklerinde olduğu gibi faşist/totaliter rejimlerin yükselişiyle birlikte eleştirel teoride dönüşüm tespit edilmiştir. Bu dönem, çalışmanın kapsamı olan yeni eleştirel teorinin de yavaş yavaş ortaya çıkışının temelleri atılmıştır.

Ernesto Laclau ve Chantal Mouffe'e göre ([1985] 2017); yeni eleştirel teorinin temelleri, Rosa Luxemburg (1871-1919), Georgi Plehanov (1856-1918), Karl Kautsky (1854-1938), Eduard Bernstein (1850-1932), George Sorel (1847-1922) ve en sonunda Antonio Gramsci (1891-1937) 
Akdağ, i̇. (2021). Politik bağlamda yeni eleştirel teori: Özne ve iktidar sorunsalları. Fiscaoeconomia, 5(2), 454-469. doi: 10.25295/fsecon.871698

tarafından şekillendirilmiştir. Klasik eleştirel teori, Marx öncülüğünde toplumsal yapıyı ekonomi altyapı, politika, ideoloji ve felsefe üstyapı olarak bir bütün olarak kavrarken, yeni eleştirel teorinin kökenleri olan yukarıda belirtilen düşünürler bu toplumsal yapının bütünlüğünü parçalamaya ve giderek üst yapı denilen politika, ideoloji ve felsefe kerteleri üzerinden çalışmalara başlamışlardır. Özerkleşen politika, ideoloji ve felsefe kerteleriyle birlikte yeni eleştirel teori son şekline ulaşmıştır.

Yeni eleştirel teori kendisine, post modern yaklaşımla birlikte felsefi bir zemin bulmuştur. Stuart Sim'e göre (2020: 3), felsefe de post modernizm, büyük anlatılara karşı ve anti-temelci bir yaklaşım içerisindedir. Sistematik, büyük anlatılar yapan ve insanlığı tarihsel bir sona götürecek anlatılar post modernizmin reddettiği bir biçimdir. Yine yukarıda belirttiğimiz üzere ekonomi altyapı ve politika, ideoloji üstyapı şeklindeki yapı anlayışlarına karşı çıkmış ve bir çeşit yapı bozum yapmıştır. Böylece, post modernizm, anti-temel bir anlayış geliştirmiştir. Post modernizme göre özneyi inşa eden, söylemdir. Yeni eleştirel teori, yapısalcı yaklaşımın eleştirisi üzerine yükselmiştir. Yapısalcılığın kurucularından Ferdinand Saussure'ın (2014) belirttiğinin aksine özne, bir gösterilen değildir ve bir gösteren yoktur. Kısaca bir gösterge (yapı) de yoktur. Bunun yerine özne konumları vardır. Böylece yeni eleştirel teori, yapısalcı yaklaşımın yapı anlayışını yapı bozuma uğratmıştır.

Yeni eleştirel teori, Batı Marksizminin ortaya çıkışı ve gelişmesi ile kendisini kuramsallaştırmıştır. Yeni eleştirel teori kendisini, eski eleştirel teoriden ayırmıştır. Perry Anderson (2019: 145), 1968 Gençlik Hareketlerinin bir dönüm noktası olduğunu belirtmiştir ve eski teoriden yeni teoriyi ayıran en önemli farkın, eski teorinin, teori ve pratiği birleştirdiğini ancak yeni teorinin, teoriyi pratikten ayırdığını ve teori üzerine yoğunlaştığını ileri sürmüştür. Yine Anderson'a göre (2019: 165); klasik teori ile yeni teori arasında teori-pratik ilişkisi çerçevesinde yapısal karşıtlık vardır ve bunun sebebi de işçi sınıfı hareketinin yenilgisidir. Buradan şu sonuç çıkarılabilir ki yarın iş̧̧i sınıfı hareketi yeniden yükselişe geçtiğinde klasik teori ile yeni teori arasındaki yapısal karşıtık sona erebilecektir. Bu çerçevede, Anderson'a göre, klasik teori ile yeni teori arasında bir kopuş yoktur. Sadece yapı, özne ve pratik denkleminde, pratik yokluğu, yapısal bir fark yaratmıştır ve pratiğin yükselişiyle birlikte bu fark kapanabilecektir. Dolayısıyla, klasik teori ile yeni teori arasında bir süreklilik ilişkisi vardır.

Razmig Keucheyan, yeni eleştirel teori mensuplarını, konumlarına göre, eski teori ile karşılaştırmalı olarak altı kategoride ele almıştır. Keucheyan'a göre (2016: 79-102) yeni eleştirel teori mensupları; ilk olarak, saf değiştirenler veya eleştirel teoriyi bırakanlar; ikinci olarak, karamsarlar veya sisteme uyum sağlayanlar; üçüncü olarak, direnişçiler veya duruşlarını değiştirmeyenler; dördüncü olarak, yenilikçiler veya eski teoriyi melezleştirenler; beşinci olarak, uzmanlar veya analizleriyle egemen söylemin karşıtında uzman olanlar; son olarak, yöneticiler veya pratik siyasetin içerisinde yer alanlar olarak konumlanmışlardır.

Yeni eleştirel teoriler üzerine çalışan düşünür Keucheyan'a göre (2016: 14); teoriler temel karakteristiklerini, içinde geliştiği tarihsel koşullardan almaktadır ve klasik teori, önemli ekonomik, politik kriz dönemlerinde ortaya çıkmıştır ve yeni eleştirel teorinin temelleri kapitalizmin istikrarlı döneminde ortaya çıkmıştır. Keucheyan (2016: 19), yeni eleştirel teorinin belirginleşmesini, Perry Anderson gibi işçi sınıfın yenilgisine bağlamaktadır. Yeni eleştirel teorinin temelleri konusunda Keucheyan (2016: 43), klasik teori ile bir süreklilik tespit 
Akdağ, ì. (2021). Politik bağlamda yeni eleştirel teori: Özne ve iktidar sorunsalları. Fiscaoeconomia, 5(2), 454-469. doi: 10.25295/fsecon.871698

etmektedir ve yeni eleştirel teorinin temellerinde Marksizm ve yapısalcılık olduğunu ileri sürmüştür. Özetle, Keucheyan'a göre klasik teori ile yeni teori arasında bir süreklilik vardır.

Tony Smith, Anderson ve Keucheyan'dan farklı olarak olguyu ele almıştır. Smith'e göre (1993: 3); postmodern sosyal teorisyenler, Marksizm içerisindeki Hegel etkisini reddetme eğilimindedir. Hegel etkisi Marksizmden dışlanınca, Marksizmin tarihselcilik kategorisinin de reddedilmesi gündeme gelmektedir ve ortaya çıkan yeni durum, klasik teoriyle yeni teori arasında bir kopuş durumunu işaret etmektedir. Böylece, Anderson ve Keucheyan'ın süreklilik yaklaşımının yanında Smith'in kopuş yaklaşımı da karşımıza çıkmaktadır.

Literatüre bakıldıktan sonra, bu çalışmanın temel hipotezi, klasik eleştirel teori ile yeni eleştirel teori arasındaki ilişkiyi ne süreklilik ne de kopuş çerçevesinde savunmaktadır. Bunların yerine, önerilen yeni ilişki biçimi süreklilik içerisinde kopuş ilişkisidir. Bu, metafizik yerine diyalektik bir bağlantıdır. Yeni eleştirel teori, klasik teorinin kavramlarını eleştirerek kendisini yeniden konumlandırmıştır. Dolayısıyla, bu yanıyla, ilişkinin biçimi süreklilik ilişkisidir. Ancak, klasik teorinin kavramlarını, yeni eleştirel teori, yoksanarak aşmıştır. Bu çerçevede ilişki biçimi kopuştur. Yeni eleştirel teoriyle klasik teori arasındaki ilişkiyi bütünsel olarak ele alırsak, bu bağlantı biçimini süreklilik içerisinde kopuş ilişkisi olarak adlandırabiliriz.

\section{Yeni Eleştirel Teori ve Özne Sorunsalı}

Eleştirel teorinin tarihsel gelişiminde önemli bir sorunsal; özne sorunsalıdır. 'Toplumsal hayatta başat olan özne ne?', 'Toplumsal dönüşümü sağlayacak özne/özneler ne?' soruları, klasik eleştirel kuram ile yeni eleştirel kuram arasında önemli bir süreklilik içerisinde kopuş meselesidir. Karl Marx, toplumsal yaşam üzerine teorisini kuramsallaştırırken temel hareket noktasını; sınıflar üzerine kurmuştu. Kapitalist toplum içerisinde Marx (2015a), üç büyük toplumsal sınıf belirlemiştir;

"Gelir kaynakları sırasıyla ücret, kar ve toprak rantı olan salt emek gücü sahipleri, sermaye sahipleri ve toprak sahipleri, yani ücretli emekçiler, kapitalistler ve toprak sahipleri, kapitalist üretim tarzına yaslanan modern toplumun üç büyük sınıfını oluşturur."

Bu çerçevede Marx, toplumsal yaşamı, üretim ilişkileri çerçevesinde sınıfların hiyerarşik eklemlenmesi üzerinden tanımlamıştır. Kapitalist üretim tarzında, temel olarak, iki sınıflı bir yapı kurmuştur ve kutuplardan birincisi burjuvazi ve diğer kutup ise proletaryadan oluşan bütünsel bir yapı olarak biçimlendirmiştir. Toplumsal yapıyı dönüştürecek gücü ise ayrıcalıklı özne olarak tanımladığı proletarya veya işçi sınıfı olarak belirlemiştir.

Klasik teori, Marx'ın bu sınıfsal özne yaklaşımına genel olarak bağlı kalmıştır. Toplumsal hayatı, bütünüyle sınıfsal hiyerarşiden oluşan bütün olarak kabul etmiştir. Bu sınıflar arasında ilişki çerçevesinde, toplumsal hayatın çelişkili yapısına son verecek güç olarak sınıf olarak tanımlamıştır. Bu yanıyla işçi sınıfı, ayrıcalıklı bir özne olarak a priori bir kategori olarak kabul edilmiştir. Burada, tabi sınıf/gruplar arasında işçi sınıfını, ayrıcalıklı ve hegemonik bir güç olarak gören anlayış söz konusudur.

Yeni eleştirel teori, özne sorunsalını ve konum itibarıyla pratik yapısını klasik teoriden almıştır. Bu biçimiyle bir süreklilik vardır. Ancak özne konusunda, klasik teoriden bir kopuş yaşamıştır. 
Akdağ, ì. (2021). Politik bağlamda yeni eleştirel teori: Özne ve iktidar sorunsalları. Fiscaoeconomia, 5(2), 454-469. doi: 10.25295/fsecon.871698

Yeni eleştirel teoride özne, klasik teorinin sınıfları ve işçi sınıfı değil kimliklerdir. Böylece tekil özne anlayışından çoğul özneler anlayışına bir geçiş yaşanmıştır. Bu özne, nesnel koşulların belirlediği sabit bir özne değil, onun yerine yüzergezer bir öznedir. Yeni eleştirel teori, sabitliği, özcülük olarak reddetmiştir. Laclau ve Mouffe'e göre (2017: 185); Özne, nesnel üretim ilişkileri içerisinde değil söylem aracılığıyla kurulmaktadır. Bu noktada belirleyici olan özne değil, özne konumlarıdır.

Laclau ve Mouffe (2017: 191) öncelikle klasik teorinin veya Marksist geleneğin özne anlayışını eleştirir ve şu görüşü ileri sürer;

“(Marksist gelenekte) özneler, üretim ilişkileri içindeki konumlarının belirlediği çıkarlar çevresinde birliklerini kuran toplumsal sınıflardır...' 'ş̧̧̧i sınıfı' ifadesi, üretim ilişkileri içindeki özgül bir özne konumunu tanımlamak için ve bu özne konumunda bulunan failleri adlandırmak için olmak üzere iki farklı biçimde kullanılır. Bundan doğan muğlaklık, bu faillerin yer aldıkları diğer konumların da 'işçi sınıfı konumları' olduğu şeklindeki, mantıksal bakımdan gayrimeşru sonuca kayılmasına izin verir."

Buradan hareketle Laclau ve Mouffe, bir başka ifadeyle yeni eleştirel teori, özne anlayışını ortaya koymaktadır. Laclau ve Mouffe'a göre (2017: 234);

"Hegemonik politika biçiminin -ki eklemleyici pratikler toplumsal bölünme ilkesinin kendisini belirlemeye başladıklarında, bu biçim, kendini bütün kolektif kimliklerin ortaya çıkışının bir koşulu olarak dayatır- genelleşmesi sürecini betimlemekte ve aynı zamanda da 'sınıf mücadelesi'nin, otomatik ve a priori bir biçimde, bu bölünme ilkesinin temeline yerleştirilmesi tutkusunun boşunalığını göstermektedir."

Bu bağlamda, yeni eleştirel teori, toplumsal özneyi söylem yoluyla kurulan kolektif kimlikler olarak tanımlamıştır ve klasik teorinin sınıf özne anlayışını açık olarak reddetmiştir. Önemli olan, özne değil özne konumlarıdır. Yeni eleştirel teorinin diğer temsilcilerine baktığımız zaman bu özne anlayışını yakından görebiliriz. E. Laclau ve C. Mouffe yanında yeni eleştirel teori temsilcileri olan Slavoj Zizek, Jacques Ranciere, Alain Badiou de bu yeni özne anlayışını gözlemleyebiliriz. Ranciere'e göre (2009: 117); özneye ulaşmak için hayaletleri baş aşağı çevirmek gereklidir. Zizek'e göre (2012: 446); özneler, kendilerini köklü bir biçimde belirsiz ve dayatılmıs maskeler içerisinde yer almaktadır ve maskelerin ardında hiçlikten başka bir şey yoktur. Badiou'ya göre (2005: 396); özne, prosedürün yerel görünüşüdür. Tüm bu gelenekte görülen, sınıf ve birey gibi sabit özneler yerine hareketli ve söylemle kurulan öznelerdir.

Yeni eleştirel teorinin özne anlayışlarının temelinde, felsefi olarak yapı bozum anlayışı bulunmaktadır. Yapı bozum anlayışı temellerini yapısalcı yaklaşımın eleştirisinden almıştır. Özne konusunda yeni eleştirel teori, referansını yapısalcı dil bilimi eleştirerek kurgulamıştır. Stuart Sim (2020: 4), Ferdinand Saussure'ın kuramsallaştırdığı dilbilim modelinin, yapısalcı anlayışın temeli olduğunu ileri sürmüştür. Yapısalcı dilbilimci Saussure (2014) dili, bir gösterge (yapı) olarak tasarlamıştır. Dil bir gösterge ise, bir gösteren (sözcük) ve bir gösterilen (kavram) ilişkisi söz konusudur. Özne, yapının belirlediği ölçüde kendisine varlık bulmaktadır. Burada determinist bir anlayış vardır.

Yeni eleştirel teori, Saussure'ın yapısal anlayışını, ontolojik olarak reddetmiştir. Jacques Derrida, Saussure'ın dilbilimsel modelini yapı bozuma uğratmıştır. Derrida, temel tezi, dilin 
Akdağ, i. (2021). Politik bağlamda yeni eleştirel teori: Özne ve iktidar sorunsalları. Fiscaoeconomia, 5(2), 454-469. doi: 10.25295/fsecon.871698

yani sistemlerin muğlak olmasıydı. Derrida'ya göre (1982: 3), Fransızca sözcük difference ile differance, farklı anlamları taşıyan sözcükler olmakla birlikte aynı şekilde telaffuz edilmektedir. Dolayısıyla gösteren muğlaktır. Konuşurken, iki kelimeyi aynı şekilde telaffuz eden kişinin neyi kastettiği anlaşılamamaktadır. Dolayısıyla gösterge (yapı) muğlaktır. Bu durumda göstergenin (yapı) yapı bozuma uğratılması gereklidir. Belirleyici olan söylemdir. Bu çerçevede yeni eleştirel teori, özneyi, söylem aracılığıyla kurmaktadır. Bir başka ifadeyle, Saussure'ın göstergesinde temel olan gösterileni, gösteren de gösterilmektedir. Bu zincir sonsuza kadar uzamaktadır. Kısaca söylem, her şeyi tanımlamaktadır. Böylece özne, söylem ile inşa edilmektedir. Gösterge olmadığına göre önemli olan özne değil konumudur.

Yeni eleştirel teori, klasik teorinin özgürleşme öznesi olan iş̧̧i sınıfı yerine, halk kavramını koymuştur. Keucheyan'a göre (2016: 74); (yeni eleştirel teori) Ernesto Laclau, Benedict Anderson, Tom Nairn, Etienne Balibar halk kavramını farklı şekilde sorgulamışlar ve sonuçta halk kategorisini özgürleşme öznesi olarak kabul etmiştir. Laclau bu durumu şu şekilde belirlemiştir (2018: 192);

“...demokrasi yalnızca, ortaya çıkışı eşdeğer talepler arasındaki yatay eklemlenmeye bağlı olan demokratik bir öznenin var oluşu üzerine oturtulabilir. Boş bir gösteren tarafından eklemlenen eşdeğer talepler topluluğu, bir 'halk'ı inşa eden şeydir. O halde demokrasinin olanaklıı̆ı̆ının kendisi, demokratik bir "halk'ın kurulmasına bağlıdır."

Sonuç olarak, Keucheyan (2016: 231), 1960 öncesi özgürleşme öznesi olan ve 1960 sonrası karmaşık bir hale gelen toplumda, özgürleşme öznelerinin ortaya çıkışını bir kopuş olarak görmemektedir. Bunda en önemli sebebi, 1960 öncesi işçi sınıfının siyasal hegemonyayı elinde tutması ve 1960 sonrası işçi sınıfının da otonom parçalara bölünmesi olarak görmektedir. Bu çalışmaya göre, 1960 öncesi klasik teori ile 1960 sonrası yeni teori arasında süreklilik içerisinde kopuş ilişkisi vardır. Aralarındaki süreklilik, özgürleşme öznesinin, toplumun tabi sınıflarından/gruplarından varlık bulmasıdır. 1960'lara kadar bu tabi sınıf/grup içerisinde işçi sınıfı hegemonyayı elinde tutmuş ve klasik teori, onu, özgürleşme öznesi olan ayrıcalıklı özne konumuna yerleştirmiştir. Yeni eleştirel teori sınıf yapısını parçalamış ve özgürleşme öznesi olarak kolektif kimliklerden teşekkül bir halk kavramı koymuştur. Burada bir kopuş ilişkisi vardır. Bir başka ifadeyle, klasik teoriyle yeni teori arasında süreklilik içerisinde kopuş ilişkisi gerçekleşmiştir.

\section{Yeni Eleştirel Teori ve İktidar Sorunsalı}

Eleştirel teori ile yeni eleştirel teorinin, süreklilik içinde kopuşu, bir başka sorunsalda, iktidar olgusunda da gözlenmektedir. Klasik eleştirel teori, ayrıcalıklı özne olarak işçi sınıfını temel alırken, işçi sınıfının, iktidara gelmesini savunmuştur. Bu durum, özne olarak iş̧̧i sınıfının ontolojik bir görevidir. Böylece klasik teorinin, iktidar sorunsalı vardır. İşçi sınıfı, iktidara geldikten sonra, toplumsal hayatta ve küresel dünyada dönüşüm gerçekleştirebilecektir.

Marx ve Engels (2017: 39), iktidar sorunsalını Gotha ve Erfurt Programları Üzerine adlı çalışmada açık olarak belirtmiştir;

"Kapitalist toplum ile komünist toplum arasında, birinin diğerine devrimci dönüşüm dönemi yer alır. Buna siyasal bir geçiş dönemi de karşılık gelir ve söz konusu geçiş döneminin devleti, proletaryanın devrimci diktatörlüğünden başka bir şey olamaz." 
Akdağ, ì. (2021). Politik bağlamda yeni eleştirel teori: Özne ve iktidar sorunsalları. Fiscaoeconomia, 5(2), 454-469. doi: 10.25295/fsecon.871698

Bu teze göre, dönüşüm, iktidarı ele aldıktan sonra sağlanacaktır. Marx ve Engels, (2018: 41) Alman Ideolojisi eserinde politik iktidar sorunsalını şu şekilde ele almıştır;

“Egemen olmak gayretindeki her sınıf, proletaryanın durumunda olduğu gibi, kendi egemenliği eski toplum biçiminin tamamının ve genel olarak egemenliğin ortadan kaldırılmasını gerektirse de kendi çıkarını yeniden genel çıkarı olarak sunmak için -ki başlangıçta bunu yapmaya mecburdur- her şeyden önce politik iktidarı ele geçirmek zorundadır."

Bu çerçeveden hareketle, klasik eleştirel teorinin temellerinin bulunduğu Marx'ın düşüncesi, iktidarı ele geçirmenin, bir zorunluluk olduğunu savunmuştur. Ancak işçi sınıfı, iktidara geldikten sonra, düşünülen dönüşümler gerçekleşebilecektir. Klasik teorinin takipçileri bu teoriye sahip çıkmıştır.

Yeni eleştirel teoriler, iktidar sorunsalına, klasik eleştirel teoriden süreklilik içerisinde kopuş perspektifinden bakmaktadır. Keucheyan'a göre (2016: 59); yeni solu, eski soldan ayıran önemli tartışma alanlarından birisi de iktidar sorunsalıdır. Yeni eleştirel teoride, 'iktidarın ele geçirilmesi gerekli midir?' sorusu temel bir sorunsal olarak kendisini ortaya koymuştur.

Yeni eleştirel teori, iktidar sorunsalını konusunda tezlerini, iki önemli düşünürün; Antonio Gramsci (1891-1937) ve Michel Foucault'un (1926-1984) teorilerine dayandırmaktadır. Gramsci'nin mevzi savaşı teorisi ve Foucault'un mikro iktidarlar teorisi, yeni eleştirel teorinin, iktidar sorunsalına yaklaşımının temellerini oluşturmuştur.

Michel Foucault (2019: 141); Özne ve İktidar kitabında iktidar(lar) anlayışını ortaya koymuştur;

"Bir toplum, bir iktidarın, sadece tek bir iktidarın uygulandığı üniter bir gövde değildir; bir toplum, gerçekte, farklı ama yine de spesifiklerini muhafaza eden iktidarların yan yana gelmesi, ilişkisi, koordinasyonu ve hiyerarşisidir...ikinci olarak, bu iktidarlar, sadece, temel olan bir tür merkezi iktidarın türevi, sonucu olarak anlaşılmamalıdırlar ve böyle anlaşılamazlar."

Böylece, Foucault, eski teorinin hedef olarak gördüğü merkezi siyasi iktidarı artık tek iktidar biçimi olarak görmemektedir. Bunun yerine toplumda, birçok mikro iktidar odakları olduğunu ileri sürmüştür. Tekillik yerine çoğulluk anlayışını koymuş ve merkezi iktidar yerine merkezsizleşmiş iktidarları toplumsal hayatın merkezine yerleştirmiştir. Dolayısıyla, yeni eleştirel teori için artık merkezi siyasal iktidarı tek başına ele geçirmek boş bir çaba olacaktır. Mesele, merkezsiz mikro iktidarların ortadan kaldırılmasıdır.

Yeni eleştirel teori, Foucault'dan çok önce Antonio Gramsci'den Doğu, Batı toplum ikiliği ve mevzi, manevra savaşları anlayışını ödünç alıp, iktidar olgusu anlayışının temelini oluşturmuştur. Gramsci'ye göre (2000: 229);

“Doğu'da, devlet her şeydir ve sivil toplum ilkel ve gevşekti. Batı'da devlet ve sivil toplum arasında uygun bir ilişki vardı. Devlet, titrediği zaman, sağlam bir sivil toplum ortaya çıkmıştı. Devlet yalnızca arkasında sağlam kalelerin olduğu bir mevzi savunmasıydı."

Dolayısıyla, Gramsci'ye göre Batı'da, Doğu'nun aksine mevzi savaşı vermek gereklidir. Güçlü bir sivil toplum olduğu için her alanda mücadele etmek zorunludur. Bu çerçevede, dönüşüm, 
Akdağ, ì. (2021). Politik bağlamda yeni eleştirel teori: Özne ve iktidar sorunsalları. Fiscaoeconomia, 5(2), 454-469. doi: 10.25295/fsecon.871698

salt devlet iktidarını elde etmekle değil toplumsal hayatın her alanında verilmesi gereken bir mücadeledir.

Yeni eleştirel teorinin, iktidar olgusunda temel dayanağı olan görüşlere baktıktan sonra yeni eleştirel teori temsilcilerinin iktidar anlayışını ele almak gereklidir. Yeni eleştirel teorinin temsilcisi John Holloway'e göre (2006: 73);

"Mücadelelerimizi devlete ya da devlet içinde nüfuz kazanmaya, devlet iktidarına mı odaklayalım? Ya da bir alternatif inşa edebildiğimiz ve böyle böyle ilerleyebildiğimiz sürece sırtımızı devlete geri mi çevirelim yoksa? Mümkün olduğunca sırtımızı devlete geri çevirmemiz gerektiğini ileri sürmek istiyorum."

Buna ek olarak Hollaway (2006: 76) eklemektedir;

“Devlete sırtımızı geri çevirmek ne demek peki? Bazı durumlarda, devleti tamamıyla görmezden gelmek, devlet üzerinde hiçbir talepte bulunmamak, sadece kendi alternatiflerimizi inşa etmeye devam etmek anlamına gelir bu."

Hollaway (2006: 75), iktidarı elde etmek yerine nasıl bir model önerdiğini şu şekilde açıklamaktadır;

“Devlet, bir şey namına kurulan bir örgütlenmedir, bizim istediğimiz şey ise kendi kendini belirlemenin örgütlenmesidir, isteklerimizi, kararlarımızı, gerekli ya da arzu edilir olduğunu düşündüğümüz şeyleri açıklıkla ifade etmemize cevaz veren bir örgütlenme biçimi, yani konsey tip örgütlenmedir."

Böylece yeni eleştirel teorilerin iktidar anlayışı belirlenmektedir. Klasik teorinin varsaydığı iktidarı elde etme anlayışı yerine, iktidardan uzak durma anlayışı, teori olarak, öne sürülmüştür. Yeni örgütlenme modelleriyle birlikte, klasik teorinin iktidar anlayışına çözüm bulmaya çalışılmıştır. Böylece bu noktada da süreklilik içerisinde kopuş ilişkisi kendisini ortaya koymuştur. İktidar sorunsalına çözümler getirirken bir süreklilik ilişkisi varken, iktidarı elde etme anlamında klasik teoriden bir kopuş söz konusudur.

\section{Politik Bağlamda Yeni Eleştirel Teori}

Tony Smith'e göre (1993: 123); post modernizmin politikası, post Marksizmin politikasının bir çeşididir. Bu çerçevede, post modernizm ile post Marksizm veya yeni eleştirel teori, politik anlamda iç içe geçmiştir. Ekonomi, politika ve ideoloji kertelerini birbirinden özerkleştiren post Marksizm, politika alanında özerk düşünme yöntemi benimsemiştir. Yeni eleştirel teorinin en başta savunduğu yaklaşım, post modernizmin büyük anlatıları reddiye yaklaşımıdır. Jean François Lyotard (1924-1998), post modernizmin felsefi yanını kuramsallaştırmıştır. Lyotard (1984), bu yanıyla, Aydınlanma anlatısı veya Marksist anlatı gibi büyük anlatıları kabul etmemiştir. Böylece, özgürleşme anlatısı da reddedilmiştir. Eskiden, bir halkın siyasal iradesi uzun dönemli amaçlara koşulurken, şimdi artık, parçalanmış kimlikler, kısa dönemli mücadelelere girmeye başlamışlardır (Grant, 2020: 27).

Marx'dan, Frankfurt Okulu'na kadar olan gelenek veya tam adıyla klasik eleştirel teori, politik olarak işçi sınıfının politik mücadelesine yol göstermek amacıyla araştırma yapmıştır. Engels, 
Akdağ, i. (2021). Politik bağlamda yeni eleştirel teori: Özne ve iktidar sorunsalları. Fiscaoeconomia, 5(2), 454-469. doi: 10.25295/fsecon.871698

bu durumu, Marx'ın (2015b: 37) opus magnum² u Kapital'de yazdığı önsözde şu şekilde açıklamıştır;

"Bu eserde (Kapital) varılan sonuçların günden güne işçi sınıfının büyük hareketinin temel ilkeleri haline geldiğini; bunun yalnızca Almanya ve İsviçre'de değil, Fransa'da, Hollanda ve Belçika'da, Amerika'da ve hatta İtalya ve İspanya'da da geçerli olduğunu; iş̧̧i sınıfının, günden güne, her yerde, bu sonuçlarda kendi durumunun ve kendi çabalarının en uygun ifadesini bulduğunu, bu hareketi yakından tanıyan hiç kimse inkâr etmeyecektir."

Yine Bronner'e göre (2011: 3); 1929'da kurulan Frankfurt Okulu'da çalışmalarında işçi sınıfının pratik hareketine yardım etmek istediğini ileri sürmüştür ancak Rus Devriminin etkileri çekilip Avrupa'da faşizm iktidar olmaya başlayınca bu pratik amaçtan çekilmiştir ve buna rağmen çalışmalarını yaparken düşüncelerinde hep işçi sınıfı olmuştur. Theodor Adorno ile birlikte Frankfurt Okulu'nun kurucusu Max Horkheimer'e göre (1972: vi);

"Bugün, çalışanların yaşam koşulları, sendika organizasyonların ve hâkim politik ve ekonomik grupların tartışmaları için saiktirler. Proletaryanın devrimci itme gücü, toplum çerçevesinde, uzun süre gerçekçi faaliyet oldu."

Ancak, 1970'lerden sonra şekillenen yeni eleştirel teoriyle durum değişmiş̧ir. Yukarıda belirtildiği şekliyle öncelikle özne sorunsalı işçi sınıfından kimliklere doğru kaymıştır. Böylece klasik teorinin sınıf yaklaşımı terk edilmiştir. Laclau ve Mouffe' göre (2017: 257);

“Bir 'evrensel sınıf' olarak işçi sınıfı anlayışı bir kez reddedildiğinde, keyfi bir şekilde 'işçi mücadeleleri' etiketi altında toplanan şeyin alanında yer alan antagonizmaların çoğulluğunu ve bunların büyük çoğunluğunun demokratik sürecin derinleştirilmesi için taşıdıkları paha biçilmez önemi kabul etmek olanaklı hale gelir."

İkinci olarak iktidarı elde etme veya sosyalizm gibi klasik teorinin temel varsayımına mesafe konmuştur. Bu çerçevede politik düzlemde yepyeni bir yaklaşım ortaya çıkmıştır. İktidar sorunsalı veya klasik teorinin sosyalizm hedefi yerine kapitalist sistem içerisinde 'radikal demokrasi' anlayışıyla ikame edilmiştir. Laclau ve Mouffe'a göre (2017: 236);

“Açık ki burada bu mücadelelerin 'politik' karakterinden, sınırlı bir anlamda, yani partiler ya da devlet düzeyindeki talepler anlamında söz etmiyoruz. Kastettiğimiz şey, bir tabiyet ilişkisi içindeki bir özneyi kuran bir toplumsal ilişkinin dönüştürülmesini hedefleyen bir hareket tarzıdır."

Buradan, Laclau ve Mouffe'un anlayışında, talepler, politik anlamda, devlet düzeyinde ileri sürülmeyecektir. Yine bu noktada Laclau ve Mouffe'un (2017: 237) politika anlayışına bakarsak;

"Görevimiz, bir tabiyet ilişkisinin baskı ilişkisi haline geldiği ve böylece de kendisi bir antagonizmanın yeri olarak oluşturduğu koşulları tanımlamaktır. Burada, 'tabiyet',

\footnotetext{
${ }^{2}$ Lat. Baş eser.
} 
Akdağ, i. (2021). Politik bağlamda yeni eleştirel teori: Özne ve iktidar sorunsalları. Fiscaoeconomia, 5(2), 454-469. doi: 10.25295/fsecon.871698

'baskı' ve 'tahakküm'ün artık eşanlamlı görülmeye başlamasıyla sonuçlanmış sayısız terminolojik kaymanın oluşturduğu bir zemine giriyoruz."

Laclau ve Mouffe, bu noktada, klasik teorinin sömürü ilişkileri yerine tahakküm veya iktidar ilişkilerini merkeze aldığını görüyoruz. Bu yeni eleştirel teoriler için, politik anlamda, şaşırtıcı bir sonuç değildir. Çünkü, ekonomi altyapıyı, politika ve ideoloji üst yapıdan koparan bir yaklaşım, ekonomik üretim ilişkilerini de görmezden gelmektedir. Artık önemli olan, Foucault'dan esinlenerek, mikro iktidarların yarattığı tahakküm ilişkilerine karşı koymaktır. Böylece sınıfsal anlamda, klasik teoriden bir kopuş gerçekleşmiştir. Klasik teori, işçi sınıfını ayrıcalıklı özne konumuna yerleştirerek, özgürleşmenin sömürü ilişkilerine son vererek gerçekleşeceğini savunmuştur. Ancak yeni eleştirel teori, işçi sınıf yerine kimlikleri özne konumuna yerleştirerek, özgürleşmenin sömürü ilişkilerine son vermek veya kapitalizmin aşılması yerine, mevcut sistemde tahakküm ilişkilerine karşı koyarak gerçekleşeceğini ileri sürmüştür. Bu bağlamda, klasik teori ve yeni teorinin sınıfsal temellerine inilecek olursa şu tablo görülebilir;

Tablo.1: Klasik Eleştirel Teori ve Yeni Eleştirel Teorinin Sınıfsal Temelleri

\begin{tabular}{|l|l|}
\hline & Sınıfsal Temelleri \\
\hline Klasik Eleştirel Teori & Iş̧̧i Sınıfı \\
\hline Yeni Eleştirel Teori & Küçük Burjuvazi Sınıfı \\
\hline
\end{tabular}

Bu bağlamda, yeni eleştirel teori, yukarıda değindiğimiz gibi, politik çerçevede, kapitalist sistemi aşma gibi bir yaklaşımı olmadığı için, mevcut sistem içerisinde, demokrasi anlayışının bir varyantı olan 'radikal demokrasi' anlayışını içselleştirmiştir. Laclau ve Mouffe (2017: 270);

"Dolayısıyla, sol bir alternatifin ancak toplumsal bölünmeyi yeni bir temel üzerine yerleştiren farklı bir eşdeğerlikler sisteminin kurulmasına dayalı olabileceği açıktır...Dolayısıyla Solun görevi liberal-demokratik ideolojiyi reddetmek değil, tersine onu radikal ve çoğul bir demokrasi doğrultusunda derinleştirmek ve genişletmek olabilir."

Sonuç olarak, yeni eleştirel teorinin politik çerçevesi, liberal demokrasinin aşılması değil onun daha derinleştirilmesi anlamına gelmektedir. Bu yanıyla yeni eleştirel teori, sistem içi bir yaklaşım biçimine gelmiştir. Klasik teoriyle süreklilik içerisinde kopuş ilişkisi kurmuştur. Toplumu, klasik teori, yapı anlamında çatışmalı bir bütün olarak kavrarken, yeni eleştirel teori antagonizmalardan oluşan parçalı bir söylem yoluyla kurulan olgu olarak tanımlamıştır. Bu yanıyla, politik anlamda, çatışmalı yapı üzerinden bir süreklilik vardır. Ancak yeni eleştirel teori, klasik eleştirel teorinin aksine, liberal demokratik düzeni aşmayı değil onu reform etmeyi önermektedir. Bu yanıyla, yeni eleştirel teori, klasik eleştirel teoriden bir kopuş yaşamaktadır. Bu biçimiyle yeni eleştirel teori, sınıfsal olarak, büyük burjuvazinin projesine dahil olmaktadır. Bu yanıyla, yeni eleştirel teori, küçük burjuva bir sınıfsal karaktere sahiptir. Klasik eleştirel teorinin sosyalizm hedefi, teleolojik denilerek, yeni eleştirel teori tarafından mahkûm edilmektedir. Buna karşın, yeni eleştirel teorinin politik anlamda hiçbir özgün projesi yoktur. Tek ortaya koyduğu proje ise liberal demokrasinin derinleştirilmesidir. Bu yanıyla yeni eleştirel teori, burjuvazinin hegemonyasına eklemlenmiştir. 
Akdağ, ì. (2021). Politik bağlamda yeni eleştirel teori: Özne ve iktidar sorunsalları. Fiscaoeconomia, 5(2), 454-469. doi: 10.25295/fsecon.871698

\section{Sonuç Yerine}

Eleştirel teori, yazılı tarihin başlarına kadar süren bir geçmişe sahiptir. Toplumsal hayatın çelişkili yapısı yanında, insanlığın, bu çelişkileri eleştirmesini getirmiştir. İnsan hem düşünen hem de eleştiren bir varlıktır. Dolayısıyla, insanlığın her dönemi, getireceği büyük maliyetlere rağmen insan, eleştirmiştir. Başlarda bireysel eleştirel tutum, ilerleyen dönemlerle birlikte sistematik bir içerik kazanmıştır. Sistematik eleştiriler, gelenekler yaratmıştır ve bu gelenekler de ekollere neden olmuştur.

Yeni eleştirel teoride, böyle bir geleneğin sonucu ortaya çıkmıştır. İsminde olduğu gibi içerisinde klasik eleştirel teorinin unsurlarını taşımıştır. Bu yanıyla, yeni eleştirel teori ile klasik eleştirel teori arasındaki ilişki süreklilik bağıntısıdır. Ancak yeni eleştirel teori, aynı zamanda, klasik eleştirel teorinin önermelerini yoksanarak aşmıştır. Bu biçimiyle, yeni eleştirel teori ile klasik eleştirel teori arasındaki ilişki bir kopuş ilişkisidir. Diyalektik bir bütünsellik içerisinde kavradığımız zaman, yeni eleştirel teori ile klasik eleştirel teori arasındaki ilişki süreklilik içerisinde kopuş ilişkisidir.

Yeni eleştirel teori, kökenlerini post modern felsefeden almıştır. Post modern felsefenin, olumsallık, merkezsizlik ve söylem gibi kategorilerini, kendi yaklaşımlarında benimsemiştir. Bu yaklaşım biçimiyle, klasik eleştirel teoriden farklılaşmıştır. Politik anlamda, klasik eleştirel teoriyi, teleolojik olarak suçlamış ve klasik eleştirel teorinin sosyalizm varsayımını kökten reddetmiştir. Bunun yerine ikame ettiği kavram, liberal demokrasinin derinleştirilmesidir. Bu anlamda yeni eleştirel teori, sistem içi bir yaklaşımdır.

Yeni eleştirel teori ile klasik eleştirel teori arasındaki farklılaşma, ilk olarak, özne sorunsalında ortaya çıkmıştır. Klasik eleştirel teori, gelenek olarak, sanayi toplumun bir mirasıydı ve sanayi toplumun getirdiği en önemli gelişme olan işçi sınıfının düşünce tarzıydı. Dolayısıyla, işçi sınıfı, temel bir özne, ayrıcalıkı bir özne ve aynı zamanda özgürleşme öznesiydi. Yeni eleştirel teori ise bilgi toplumunun bir mirasıydı ve bilgi toplumu ile gündeme gelen kimliklerin savunucusudur. Bu yanıyla, yeni eleştirel teori için özne(ler) kimliklerdir. Burada, bir özne meselesini vurgulamak açısından klasik eleştirel teori ile yeni eleştirel teori arasında bir süreklilik ilişkisi varken, ortaya koydukları özne(ler) açısından bir kopuş vardır. Sonuç, süreklilik içerisinde kopuş ilişkisidir.

Yeni eleştirel teori ile klasik eleştirel teori arasındaki bir başka farklılaşma ise iktidar sorunsalı üzerinedir. Klasik eleştirel teori, işçi sınıfının düşünce biçimi olduğu için sosyalizm hedefi ile iktidara gelmeyi savunmuştur. Toplumsal hayat ve küresel dünya, işçi sınıfının iktidara gelmesi sonucu dönüştürülecektir. Yeni eleştirel teori ise, kimliklerin savunucusu olarak, sosyalizm hedefini reddettiği için iktidar olgusuna da mesafelidir. Yeni eleştirel teoriye göre, iktidara gelmenin önemi yoktur. Bunun için devlete mesafeli durmak gereklidir. İktidar olgusunu ele alış bakımından klasik eleştirel teori ile yeni eleştirel teori arasında bir süreklilik varken iktidar olgusuna faklı bakış açıları bir kopuş getirmiştir. Sonuç, süreklilik içerisinde kopuştur.

Politik çerçevede, klasik eleştirel teori ile yeni eleştirel teori arasında sınıfsal farklılıklar kendisine varlık bulmuştur. Klasik eleştirel teori, işçi sınıfının düşünme tarzıyken yeni eleştirel teori küçük burjuva bir karaktere sahiptir. Politik anlamda, klasik eleştirel teori, özgürleşmeyi sosyalizm içerisinde ararken yeni eleştirel teori, liberal demokrasi içerisinde reform yapmayı 
Akdağ, i. (2021). Politik bağlamda yeni eleştirel teori: Özne ve iktidar sorunsalları. Fiscaoeconomia, 5(2), 454-469. doi: 10.25295/fsecon.871698

savunmuştur. Dolayısıyla, yeni eleştirel teori ile klasik eleştirel teorinin politik hedefleri birbirinden farklılaşmıştır. Yeni eleştirel teori sistem içiyken klasik eleştirel teori sistem dışıdır. Yeni eleştirel teori, burjuvazinin hegemonyasına eklemlenmiştir. Sonuç olarak, aralarındaki ilişki, süreklilik içerisinde kopuş ilişkisidir.

\section{Kaynakça}

Anderson, P. (2019). Batı Marksizmi Üzerine Düşünceler, çev. Bülent Aksoy, İstanbul: İletişim

Badiou, A. (2005). Being and Event, trans. Oliver Feltham, Continuum

Bronner, S. E. (2011). Critical Theory A Very Short Introduction, Oxford University Press

Derrida, J. (1982). Margins of Philosophy, trans. Alan Bass, The Harvester Press

Foucault, M. (2019). Özne ve iktidar, çev. Işık Ergüden ve Osman Akınhay, İstanbul: Ayrıntı

Gramsci, A. (2000). The Gramsci Reader Selected Writings 1916-1935, ed. David Forgacs, New York University Press

Grant, I. H. (2020). "Postmodernizm ve Politika”, Routledge Postmodernizm Rehberi, ed. Stuart Sim, çev. Mukadder Erkan ve Ali Utku, Ankara: Nobel

Holloway, J. (2006). "iktidar ve Devlet”, iktidar Olmadan Dünyayı Değiştirmek mi? Dünyayı Değiştirmek için iktidar Olmak mı?, ed. Daniel Bensaid, John Hollaway, Alex Callinicos, Hillary Wainwrighr, Michael Lowy, çev. Erkal Ünal, İstanbul: Yazın

Horkheimer, M. (1972). Critical Theory Selected Essays, trans. Matthew J. Connell, New York: Continuum

Keucheyan, R. (2016). Aklın Sol Yarısı Yeni Eleştirel Düşünceler Atlası, çev. Selen Şahin, İstanbul: Iletişim

Laclau, E. (2018). Popülist Akıl Üzerine, çev. Nur Betül Çelik, Ankara: Epos

Laclau, E. ve C. Mouffe. (2017). Hegemonya ve Sosyalist Strateji, çev. Ahmet Kardam, İstanbul: Iletişim

Lyotard, J. F. (1984). Postmodern Condition, University of Minnesota Press

Marx, K. ve F. Engels. (2018). Alman Ideolojisi, çev. Olcay Geridönmez ve Tonguç Ok, İstanbul: Kor

Marx, K. ve F. Engels. (2017). Gotha ve Erfurt Programları Üzerine, çev. Erkin Özalp, İstanbul: Yordam

Marx, K. ([2015a). Kapital c. III, çev. Mehmet Selik ve Erkin Özalp, İstanbul: Yordam

Marx, K. (2015b). Kapital C. I, çev. Mehmet Selik ve Nail Satlıgan, İstanbul: Yordam

Ranciere, J. (2009). Filozof ve Yoksulları, çev. Aziz Ufuk Kılıç, İstanbul: Metis 
Akdağ, ì. (2021). Politik bağlamda yeni eleştirel teori: Özne ve iktidar sorunsalları.

Fiscaoeconomia, 5(2), 454-469. doi: 10.25295/fsecon.871698

Saussere, F. (2014). Genel Dilbilim Yazıları, çev. Savaş Kılıç, İstanbul: İthaki

Sim, S. (2020). "Postmodernizm ve Felsefe", Routledge Postmodernizm Rehberi, ed. Stuart Sim, çev. Mukadder Erkan ve Ali Utku, Ankara: Nobel

Smith, T. (1993). Dialectical Social Theory and Its Critics From Hegel to Analytical Marxism and Postmodernism, State University of New York Press

Zizek, S. (2012). Gıdıklanan Özne, çev. Şamil Can, Ankara: Epos

Etik Beyanı: Bu çalışmanın tüm hazırlanma süreçlerinde etik kurallara uyulduğunu yazarlar beyan eder. Aksi bir durumun tespiti halinde Fiscaoeconomia Dergisinin hiçbir sorumluluğu olmayıp, tüm sorumluluk çalışmanın yazarlarına aittir.

Ethics Statement: The authors declare that ethical rules are followed in all preparation processes of this study. In case of detection of a contrary situation, Fiscaoeconomia has no responsibility and all responsibility belongs to the authors of the study. 
Akdağ, ì. (2021). Politik bağlamda yeni eleştirel teori: Özne ve iktidar sorunsalları. Fiscaoeconomia, 5(2), 454-469. doi: 10.25295/fsecon.871698

New Critical Theory in the Context of Politics: The Problematics of Subject and Power

\section{İnan AKDAĞ}

\section{Extended Abstract}

Social structure is complex phenomenon. It includes antagonistic relationships. Therefore, antagonisms lead to criticisms of mankind. In the beginning, man looked at his environment individually, then his criticisms have looked at it systematical over time. Man criticized everything in his environment from Antique Greece. In this context, systematic approach has created traditions. The aim of this study is to analyze the critical theory which has systematic point of view and the new critical theory from which emerged. In the $20^{\text {th }}$ century, critical theory was synonymous with Frankfurt School. However, critical thinking is not the same as Marxism. Before Karl Marx, Immanuel Kant was the pioneer of critical thinking in the form of philosophy. Then the changing conditions led to transform critical theory into Marxism. The main reason for this situation is that capitalism became the dominant type of production and it transformed the social structure. The new critical theory was born in the 1960s, was a system of thought and there was a break in the continuity relationship with classical critical theory. The 1960s was an important breaking point for the world because global youth movements emerged in 1968. After 1968, the world discovered new antagonistic points from feminism, ethnicity, religion etc. Therefore, these new points led to transformation of social sciences from philosophy to politics. New approaches emerged after this period. In 1991, the collapse of USSR led to new approaches in the world. During this period, a new critical theory began to emerge in social sciences. At the beginning, it bore the traces of classical critical theory but then it seriously criticized classical critical theory. The standpoint of the new critical theory based on postmodern philosophy bears the traces of classical critical theory, but it exceeded that. The new critical theory has been based on the works of Rosa Luxemburg (18711919), Georgi Plehanov (1856-1918), Karl Kautsky (1854-1938), Eduard Bernstein (1850-1932), George Sorel (1847-1922) and Antonio Gramsci (1891-1937). While the classical critical theory postulated the social structure, formed by the economic structure and the political, ideological, and philosophical superstructures, the new critical one asserted the fragmentary structure and approved the autonomy of instances. Among the theorists of the new critical theory, Ernesto Laclau, Chantal Mouffe, Slavoj Zizek, Jacques Ranciere and Alain Boudieu. This study which examined the new critical theory in relation to subject and power has identified a break in continuity between classical critical theory and new one. Whereas the classical theory emphasizes classes in the subject of subject and highlights the working class as the privileged subject, the new critical theory substitutes subject positions for identities as plural subjects. The new critical theory is based on postmodern philosophy, which proposes a decentralized subject and an amphibious subject. The subject approach of new critical theory criticizes Marxist theory which is based on objective relations of production. Therefore, the new critical theory has broken the link with classical critical theory in the meaning of the subject. Classical critical theory saw the working class as the redemption of the subject. However, the new critical theory did not see the redemption from capitalism, but instead thought reforming in the capitalist system. If the classical critical theory defends the assumption of power, the new critical theory takes a distanced position about on the phenomenon of power. Politically, if classical critical theory seeks socialism as a political 
Akdağ, ì. (2021). Politik bağlamda yeni eleştirel teori: Özne ve iktidar sorunsalları.

Fiscaoeconomia, 5(2), 454-469. doi: 10.25295/fsecon.871698

project, the new critical theory seeks reform in liberal democracy. Classical critical theory from Karl Marx to Frankfurt School had embraced the idea of socialism as a goal of the working class. The new critical theory rejected both the working class as an object and socialism as a goal. Instead, it assumed only reforms in liberal capitalist system. As class roots, if classical critical theory is the form of thought of the working class, the new critical theory becomes the form of thought of petty bourgeoisie. Therefore, the political project of the working class is rejected by the new critical theory. The framework of this study is the new critical theory that emerged after the 1960s. The hypothesis of this study is that there is a break in the continuity relationship between the new critical theory and the classical critical theory in political terms. 